\title{
Correction to: New constraints on coseismic slip during southern Cascadia subduction zone earthquakes over the past 4600 years implied by tsunami deposits and marine turbidites
}

\section{George R. Priest ${ }^{1}$ (D) $\cdot$ Robert C. Witter ${ }^{2} \cdot$ Yinglong J. Zhang ${ }^{3} \cdot$ Chris Goldfinger $^{4}$.} Kelin Wang ${ }^{5} \cdot$ Jonathan C. Allan ${ }^{1}$

Published online: 11 July 2018

(C) Springer Nature B.V. 2018

\section{Correction to: Nat Hazards \\ https://doi.org/10.1007/s11069-017-2864-9}

This correction stands to correct Figure $7 \mathrm{c}$ listing a low minimum slip of $12 \mathrm{~m}$ for Case 2 instead of the correct value of $8 \mathrm{~m}$, as stated in the body of the text and depicted on the chart of cumulative slip. The corrected chart explanation and caption are shown below. This error did not affect any of the findings of the paper or the chart itself. This is a correction to the original article.

The original article can be found online at https://oi.org/10.1007/s11069-017-2864-9.

\section{George R. Priest}

grpriest@yahoo.com

http://www.oregongeology.org/tsuclearinghouse/

Extended author information available on the last page of the article 
a Slip from turbidite following time interval

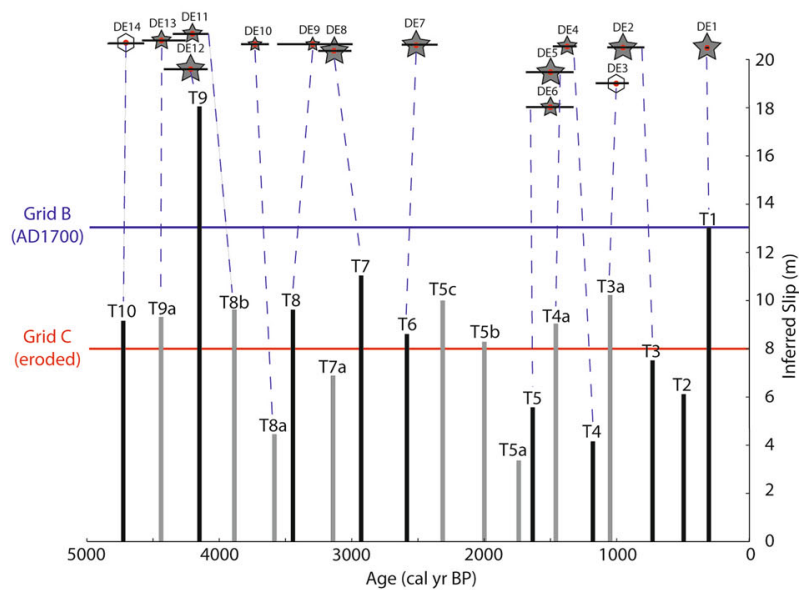

b Slip from turbidite preceding time interval

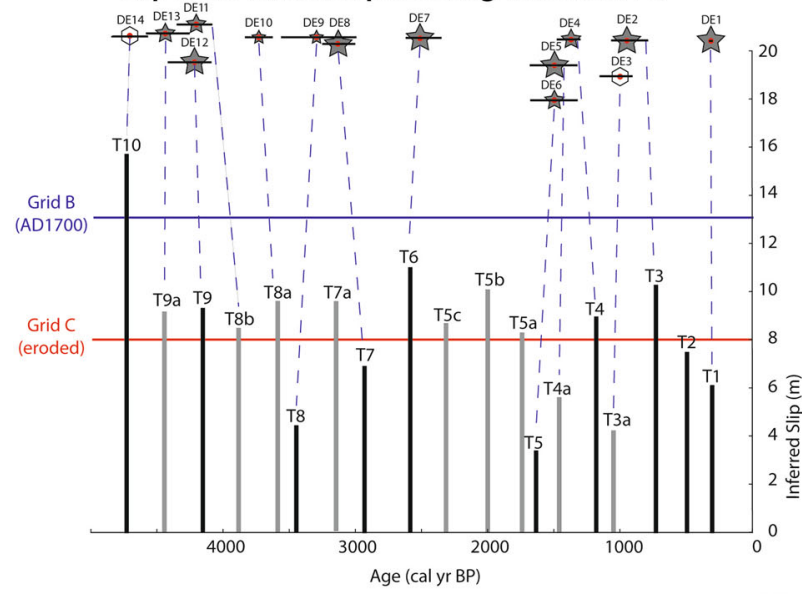

Disturbance event in Bradley
Lake with 2 sigma error on age Kelsey et al. (2005) labels

Correlation of turbidite to Bradley Lake disturbance or tsunami deposit by Goldfinger et al. (2012)

Minimum slip for lake inundation from ruptures directly offshore (most likely seaward shoreline, grid B)

- Minimum slip for lake inundation from ruptures directly offshore

(most landward shoreline, grid C)

C Cumulative slip since 4,740 cal yrs BP (T10)

200

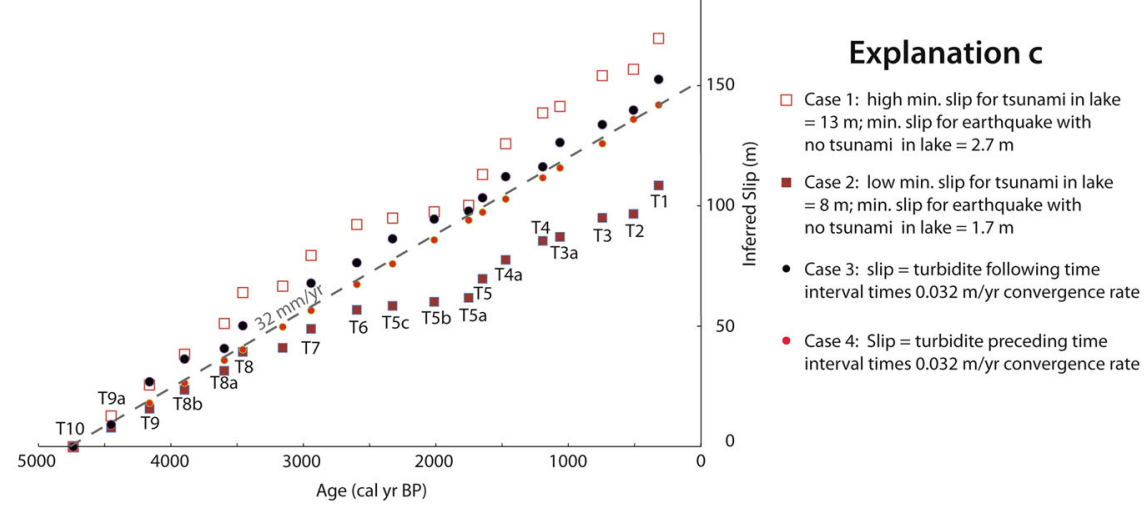


4Fig. 7 Subduction zone fault slip and slip balance over the last $\sim 4700$ years (since turbidite T10) from turbidite record at Hydrate Ridge plus one turbidite (T8a or T8b) at Rogue Apron. a Coseismic slip inferred from turbidite following time (set at $13 \mathrm{~m}$ for the last event at $\mathrm{T} 1$ based on our simulation), b coseismic slip inferred from turbidite preceding time, c cumulative slip since turbidite T10 for four cases: Case 1, slip = high minimum to get tsunamis into Bradley Lake of $13 \mathrm{~m}$ and, for turbidites T2, T5a, T5b, and T5c without matching tsunami deposits in the lake, the high minimum of $2.7 \mathrm{~m}$ to produce a turbidite; Case 2 , slip = low minimum to get tsunamis into Bradley Lake of $8 \mathrm{~m}$ and, for turbidites T2, T5a, T5b, and T5c without matching tsunami deposits in the lake, the low minimum of $1.7 \mathrm{~m}$ to produce a turbidite (filled squares); Case 3, turbidite follow times; and Case 4, turbidite preceding times. Data are from Goldfinger et al. (2012, 2013b). Min. minimum. Note that total slip must approximately balance with total plate convergence for either Case 3 or Case 4, since they both use inter-event age data.

\section{Affiliations}

\section{George R. Priest ${ }^{1}$ (D) $\cdot$ Robert C. Witter ${ }^{2} \cdot$ Yinglong J. Zhang $^{3} \cdot$ Chris Goldfinger $^{4}$ • Kelin Wang ${ }^{5} \cdot$ Jonathan C. Allan ${ }^{1}$}

Robert C. Witter

rwitter@usgs.gov

Yinglong J. Zhang

yjzhang@vims.edu;

http://www.vims.edu/about/directory/faculty/zhang_yj.php

Chris Goldfinger

gold@oce.orst.edu;

http://www.coas.oregonstate.edu/index.cfm?fuseaction=content.search \&

searchtype $=$ people $\&$ detail $=1 \&$ id $=540$

Kelin Wang

kwang@nrcan-rncan.gc.ca;

http://cgc.rncan.gc.ca/dir/index_e.php?id=8400

Jonathan C. Allan

jonathan.allan@oregon.gov

1 Oregon Department of Geology and Mineral Industries, Newport Coastal Field Office, Newport, OR, USA

2 U.S. Geological Survey, Alaska Science Center, Anchorage, AK, USA

3 Center for Coastal Resources Management, Virginia Institute of Marine Science, Gloucester Point, VA, USA

4 Oregon State University, Corvallis, OR, USA

5 Geological Survey of Canada, Pacific Geoscience Centre, Sidney, BC, Canada 